\title{
Increases in CD4+ T lymphocytes, macrophages, neutrophils and interleukin 8 positive cells in the airways of patients with bronchiectasis
}

\author{
M Gaga, A M Bentley, M Humbert, J Barkans, F O’Brien, C G Wathen, A B Kay, \\ S R Durham
}

\begin{abstract}
Background-Bronchiectasis is a chronic suppurative lung disease characterised by irreversible dilation of the bronchi and persistent purulent sputum. The immunopathology of the disease was studied using a quantitative immunostaining technique with particular reference to $T$ lymphocytes, macrophages, and granulocytes.

Methods-Bronchial mucosal biopsy specimens were obtained by fibreoptic bronchoscopy from 12 patients with bronchiectasis (six receiving inhaled steroids) and 11 normal healthy controls. Immunostaining (APAAP method) was performed on frozen cryostat sections with a panel of monoclonal antibodies to total leucocytes (CD45), T lymphocyte phenotypic markers (CD3, CD4, CD8), macrophages (CD68), eosinophils (EG2), and neutrophils (elastase).
\end{abstract}

Results-There was a mononuclear cell infiltrate in both patients with bronchiectasis and normal controls, but an overall increase in total leucocyte cell numbers (CD45+ cells) was identified in those with bronchiectasis (median values 422 cells $/ \mathrm{mm}^{2}$ versus $113 \mathrm{cells} / \mathrm{mm}^{2}$ in control tissue, $p<0.001)$. Intense infiltration of CD3+ T lymphocytes was observed compared with healthy controls $\left(292 \mathrm{cells} / \mathrm{mm}^{2}\right.$ and 40 cells $/ \mathrm{mm}^{2}$, respectively, $p<0.001$ ). This comprised predominantly CD4+ $T$ cells $\left(118\right.$ cells $\left./ \mathrm{mm}^{2}\right)$ rather than $\mathrm{CD8}+\mathrm{T}$ cells $\left(47\right.$ cells $\left./ \mathrm{mm}^{2}\right)$. CD3+ cell counts were reduced in those subjects on inhaled steroids compared with those not receiving inhaled steroids $\left(197 \mathrm{cells} / \mathrm{mm}^{2}\right.$ versus 369 cells $\left./ \mathrm{mm}^{2}, \mathbf{p}<0.05\right)$, as were $\mathrm{CD} 4+$ cell counts $\left(82 \mathrm{cells} / \mathrm{mm}^{2}\right.$ versus 190 cells $/ \mathrm{mm}^{2}$, p $<0.05)$. Neutrophil and macrophage cell numbers were also increased in patients with bronchiectasis (114 cells $/ \mathrm{mm}^{2}$ and 213 cells $/ \mathbf{m m}^{2}$, respectively) compared with controls (41 neutrophils $/ \mathrm{mm}^{2}$ and 40 macrophages $/ \mathrm{mm}^{2}$ ). EG2+ (activated) eosinophil numbers were much lower than $T$ cells, macrophages, and neutrophils in patients with bronchiectasis but were increased compared with controls (36 cells $/ \mathrm{mm}^{2}$ versus 0 cells $\left./ \mathrm{mm}^{2}, \mathbf{p}<0.001\right)$. In view of the markedly increased neutrophil counts in patients with bronchiectasis, biopsy specimens were immunostained for interleukin 8 (IL-8) which was highly significantly increased compared with controls $\left(47\right.$ cells $/ \mathrm{mm}^{2}$ versus 15 cells $/ \mathrm{mm}^{2}$, $p<0.01)$. IL-8+ cells were less prominent in steroid treated patients than in patients not receiving treatment $\left(30 \mathrm{cells} / \mathrm{mm}^{2}\right.$ versus 60 cells $\left./ \mathrm{mm}^{2}, \mathbf{p}<0.05\right)$. A further characteristic of bronchiectasis was mucous gland hypertrophy. Gland area comprised up to $40 \%$ of the tissue in some bronchiectasis sections while no hypertrophy was noted in control biopsy specimens $(\mathbf{p}<0.05)$.

Conclusion-Airway inflammation in bronchiectasis is characterised by tissue neutrophilia, a mononuclear cell infiltrate composed mainly of CD4+ $T$ cells and CD68+ macrophages, and increased IL-8 expression. Inhaled corticosteroid treatment in patients with bronchiectasis is associated with a less marked infiltration by $T$ cells and IL-8+ cells within the bronchial mucosa, although this finding requires confirmation in a prospective placebo controlled trial.

(Thorax 1998;53:685-691)

Keywords: bronchiectasis; CD3+ cells; IL-8; cellular infiltration

Bronchiectasis is a chronic suppurative lung disease of diverse aetiology characterised by irreversible dilatation of the bronchi and persistent purulent sputum production. There is a considerable amount of information on host-microbial interrelationships ${ }^{1}$ in the pathogenesis of the disease but few data on the host mucosal cellular infiltrate. ${ }^{2}$ A previous immunohistological study observed an intense mononuclear cell infiltrate with a predominance of CD8+ T cells. ${ }^{3}$ More recent studies have shown that bronchiectasis may be characterised by either increased CD4+ or CD8+ $\mathrm{T}$ cells ${ }^{5}$ or, indeed, no predominance of either phenotype. ${ }^{6}$ There is accumulating evidence for a cell mediated pattern of immune response with infiltration of activated CD4+ T lymphocytes within the bronchial mucosa in a number of respiratory diseases such as sarcoidosis, ${ }^{7}$ fibrosing alveolitis, ${ }^{8}$ chronic bronchitis, ${ }^{9}$ and asthma. ${ }^{10}{ }^{11}$ Furthermore, increased CD4+ cells have been noted in a number of other systemic diseases including psoriasis, ${ }^{12}$ rheumatoid arthritis, ${ }^{13}$ and ulcerative colitis, ${ }^{14}$ the latter two of which are known to be associated with bronchiectasis. Our aim was to characterise fully the nature and degree 
Table 1 Clinical details

\begin{tabular}{|c|c|c|}
\hline & $\begin{array}{l}\text { Bronchiectasis } \\
(n=12)\end{array}$ & $\begin{array}{l}\text { Normal controls } \\
(n=11)\end{array}$ \\
\hline Sex $(M: F)$ & $2: 10$ & $5: 6$ \\
\hline \multicolumn{3}{|l|}{ Age (years) } \\
\hline Mean & 59.7 & 26.8 \\
\hline Range & $28-75$ & $21-39$ \\
\hline \multicolumn{3}{|l|}{$\begin{array}{l}\mathrm{FEV}_{1}(\% \\
\text { predicted })\end{array}$} \\
\hline Mean & 60.3 & 106.2 \\
\hline Range & $27-110$ & $90-123$ \\
\hline $\begin{array}{l}\text { Atopic status } \\
\text { (A:NA) }\end{array}$ & $4: 8$ & $4: 7$ \\
\hline Inhaled steroids & $6 / 12^{\star}$ & $0 / 11$ \\
\hline
\end{tabular}

$\mathrm{FEV}_{1}=$ forced expiratory volume in one second; $\mathrm{A}=$ atopic, $\mathrm{NA}$ $=$ non-atopic. All subjects were current non-smokers. ${ }^{\star}$ Two patients were taking budesonide $800 \mu \mathrm{g}$ daily and one $1200 \mu \mathrm{g}$ daily. One patient was taking beclomethasone $400 \mu \mathrm{g}$ daily and two $1000 \mu \mathrm{g}$ daily.

of the inflammatory cell infiltrate within the bronchial mucosa in patients with postinfective bronchiectasis who showed no other immunological defect or disease compared with healthy control subjects. We also compared the cellular findings in patients with bronchiectasis treated and not treated with inhaled steroids, as this medication is clinically used but efficacy is not proven in bronchiectasis.

\section{Methods}

SUBJECTS

Twelve patients with bronchiectasis and 11 healthy control subjects participated in the study. Clinical details of patients with bronchiectasis and controls are presented in table 1 . Subjects with bronchiectasis were recruited from the chest clinic at Wycombe General Hospital, High Wycombe and asymptomatic healthy controls were recruited from laboratory staff and students at the Imperial College School of Medicine at the National Heart and Lung Institute and Royal Brompton Hospital, London, UK. The diagnosis of bronchiectasis was made on the basis of a clinical history of regular mucopurulent sputum production and radiological confirmation by either chest radiography (all cases) or CT scanning (all but four cases). All patients had bilateral bronchiectasis, the most affected lobe being biopsied as follows: RLL (six cases), LLL (four cases), lingula (one case), and RML (one case). Patients with cystic fibrosis and immunoglobulin deficiencies were excluded. The aetiology of bronchiectasis was "post-infective" related to a history of severe respiratory infection in childhood in all cases. There were no infective exacerbations or treatment with oral steroids within the previous four weeks. Six of the 12 patients with

Table 2 Cell counts per $\mathrm{mm}^{2}$ expressed as median (interquartile range)

\begin{tabular}{llll}
\hline & Bronchiectasis & Normal controls & p value \\
\hline CD45 & $422(355-483)$ & $113(79-192)$ & $<0.001$ \\
Neutrophils & $114(89-146)$ & $41(35-59)$ & $<0.001$ \\
CD68 & $213(155-235)$ & $40(31-59)$ & $<0.001$ \\
CD3 & $292(98-421)$ & $40(26-91)$ & $<0.001$ \\
CD4 & $118(68-214)$ & $18(0-70)$ & $<0.001$ \\
CD8 & $47(25-75)$ & $20(10-75)$ & NS \\
EG3 & $36(21-45)$ & $0(0-15)$ & $<0.001$ \\
CD25 & $12(0-21)$ & $1(0-10)$ & NS \\
IL-8 & $47(31-60)$ & $15(6-26)$ & $<0.01$ \\
Glands & $1.05(0-13.5)$ & $0(0-0)$ & $<0.05$ \\
\hline
\end{tabular}

* Gland area/whole section area ratio \%. bronchiectasis were receiving inhaled steroids $(400-1200 \mu \mathrm{g} /$ day $)$. Atopic and non-atopic individuals were included. Atopic status was confirmed by positive skin prick test to at least one of a panel of common aeroallergens (including house dust mite, grass pollen, cat dander, dog hair, feathers, Cladosporium, Alternaria and Aspergillus), a raised total IgE level, or the presence of specific IgE (IgE RAST) to house dust mite, cat dander, or grass pollen. Four of the 12 patients showed evidence of mild airflow reversibility of $>15 \%$ to $\beta_{2}$ agonists (three of these were on inhaled steroids). Airways responsiveness to methacholine was not assessed because of the severity of baseline airflow obstruction in all patients studied. Asymptomatic healthy control subjects had no evidence of chronic disease or airflow obstruction and spirometric test results were within normal limits. Atopic status was also determined by performance of skin prick tests using the same panel of aeroallergens as were used for bronchiectasis patients. None of the subjects had had a respiratory tract infection within the previous four weeks and they were not taking oral or inhaled medication. All were non-smokers except for one patient with bronchiectasis who was an ex-smoker for the last 10 years with a smoking history of less than five pack-years.

The study was performed with the written and informed consent of all subjects and the approval of the ethics committees of both participating centres.

\section{STUDY DESIGN}

The subjects attended on two occasions. At the first visit a full history and examination was performed, a respiratory questionnaire was completed, and skin prick tests or IgE RAST tests were performed to common aeroallergens. Baseline spirometric values $\left(\mathrm{FEV}_{1}\right)$ and reversibility were documented. Bronchoscopic examination was performed at a second visit.

\section{BRONCHOSCOPY}

Identical conditions including biopsy forceps and methods of sampling were employed at both Wycombe Hospital and Royal Brompton Hospital. Subjects were fully informed prior to the procedure including potential complications. They were premedicated with $0.6 \mathrm{mg}$ atropine intravenously 30 minutes before the procedure. Immediately prior to bronchoscopy midazolam up to $7 \mathrm{mg}$ was given intravenously. The nose and throat were anaesthetised topically with lignocaine spray; $4 \%$ lignocaine was applied through the bronchoscope channel to the vocal cords and $2 \%$ lignocaine was used to anaesthetise the upper airways. Oxygen at 4 $1 /$ min was administered via nasal cannulae throughout the procedure and arterial oxygen saturation was monitored throughout by pulse oximetry. The bronchoscope used was an Olympus model BFP20 with a $2.2 \mathrm{~mm}$ wide biopsy channel (Olympus, Tokyo, Japan). Olympus alligator forceps model FB15C were used to take 4-6 biopsy specimens from segmental divisions of the main bronchi. The site of biopsy was directed by prior radiographic 


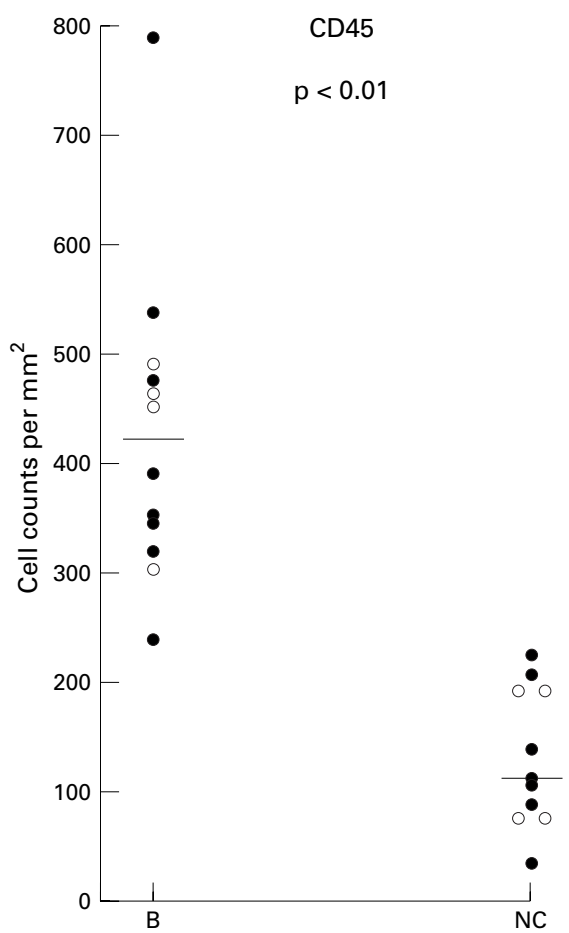

Figure 1 CD45+ cell counts in the bronchial mucosa of 12 patients with bronchiectasis $(B)$ and 11 normal control subjects $(\mathrm{NC}) ; \circ=$ atopic; $\bullet$ = non-atopic. Results are expressed as number of cells per $\mathrm{mm}^{2}$ of tissue section examined (average of at least two sections). Horizontal bars represent median values.

assessment of affected areas and by direct endoscopic appearances of mucosal swelling, erythema, and the presence of mucus and/or distortion of the bronchi. All patients tolerated fibreoptic bronchoscopy well and there were no untoward side effects.

IMMUNOCYTOCHEMISTRY

Each biopsy specimen was placed in phosphate buffered saline and within 30 minutes it was embedded in OCT medium and snap frozen in isopentane precooled in liquid nitrogen prior to storage at $-80^{\circ} \mathrm{C}$. Biopsy specimens from High Wycombe were transported on dry ice to London and stored at $-80^{\circ} \mathrm{C}$ prior to cryostat sectioning. Sections of $6 \mu \mathrm{m}$ were cut on a Bright cryostat and three consecutive sections were placed on microscope slides. They were air dried for one hour, fixed in equal parts of acetone and methanol for five minutes, and further air dried for one hour. The slides were then wrapped in pairs back to back in aluminium foil and stored at $-20^{\circ} \mathrm{C}$ prior to immunostaining. The sides were allowed to defrost in their foil covering. Mononclonal

Table 3 Cell counts per $\mathrm{mm}^{2}$ in patients with bronchiectasis receiving and not receiving steroids expressed as median (interquartile range)

\begin{tabular}{llll}
\hline & Bronchiectasis (on steroid) & Bronchiectasis (off steroid) & p value \\
\hline CD45 & $403(304-466)$ & $434(349-536)$ & $\mathrm{NS}$ \\
Neutrophils & $127(78-195)$ & $114(110-123)$ & $\mathrm{NS}$ \\
CD68 & $186(145-213)$ & $220(197-245)$ & $\mathrm{NS}$ \\
CD3 & $197(149-306)$ & $369(278-440)$ & $<0.05$ \\
CD4 & $82(62-123)$ & $190(112-275)$ & $<0.05$ \\
CD8 & $37(0-66)$ & $68(46-77)$ & $\mathrm{NS}$ \\
EG3 & $43(35-55)$ & $22(20-36)$ & $\mathrm{NS}$ \\
CD25 & $4(0-12)$ & $17(10-30)$ & $\mathrm{NS}$ \\
IL-8 & $30(29-48)$ & $60(45-73)$ & $<0.05$ \\
\hline
\end{tabular}

antibody staining was detected by a modification of the alkaline phosphatase anti-alkaline phosphatase method described by Mason and Sammons. ${ }^{15}$ This technique has been described in detail previously. ${ }^{16} 20 \%$ normal human serum was used to prevent non-specific binding of the second and third layer antibodies. System and specificity controls were included in each staining run using human tonsil obtained at routine tonsillectomy operations and a mouse $\operatorname{IgG}_{2 \alpha}$ myeloma protein as a negative control. Sections from all bronchial biopsy specimens from both bronchiectasis patients and controls were immunostained for each monoclonal antibody in a single experiment. Inevitably occasional sections were lost, although repeat staining of these was not performed. The monoclonal antibodies used were anti-CD45 (total leucocytes), anti-CD3 (pan-T lymphocytes), anti-CD4 ( $\mathrm{T}$ helper cells), anti-CD8 ( $\mathrm{T}$ suppressor cells), antiCD25 (anti-interleukin-2-receptor) (BectonDickinson, Cowley, Oxford, UK), Dakoelastase (anti-neutrophil elastase), anti-CD68 (macrophages) (Dako Ltd, High Wycombe, UK), EG2 (anti-ECP/eosinophils) (Sanbio V, Netherlands), and IL-8 (Serva, Heidelberg, Germany).

The gland and total section area in each biopsy specimen was measured in $\mathrm{mm}^{2}$ using a calibrated graphics tablet (Summasketch Plus; Summagraphics Corporation, Fairfield, CT, USA) linked to a computer (Hewlett Packard Vectra 286/12 PC; Hewlett Packard International, Palo Alto, CA, USA) and a sidearm microscope attachment that enabled simultaneous viewing of both the tissue section under and the graphics tablet. The gland area was then expressed as a percentage of the whole section area.

\section{QUANTITATION}

Biopsy specimens were coded and sections counted in a blinded fashion by a single operator using a $\mathrm{BH} 2$ microscope (Olympus) and an eyepiece graticule at a magnification of $\times 200$. The numbers of positively stained cells were counted in the whole area of the section beneath the basement membrane. The cell counts were expressed as the number per $\mathrm{mm}^{2}$. Serial $6 \mu \mathrm{m}$ sections were obtained and stained with each antibody. A minimum of two sections $36 \mu \mathrm{m}$ apart were stained and counted for each antibody from each biopsy specimen and the mean value was calculated by two observers. The coefficient of variation for repeat cell counts for the same observer for each antibody was $<5 \%$. We also confirmed that interobserver coefficients of variation were $<10 \%$ for all monoclonal antibodies employed in the study.

\section{STATISTICAL ANALYSIS}

Cell counts in the bronchial mucosa were expressed per $\mathrm{mm}^{2}$. The numbers of positive cells for most of the monoclonal antibodies employed showed a positive skew distribution and therefore were analysed using nonparametric statistics. Between group analysis comparing cell counts from biopsy specimens 


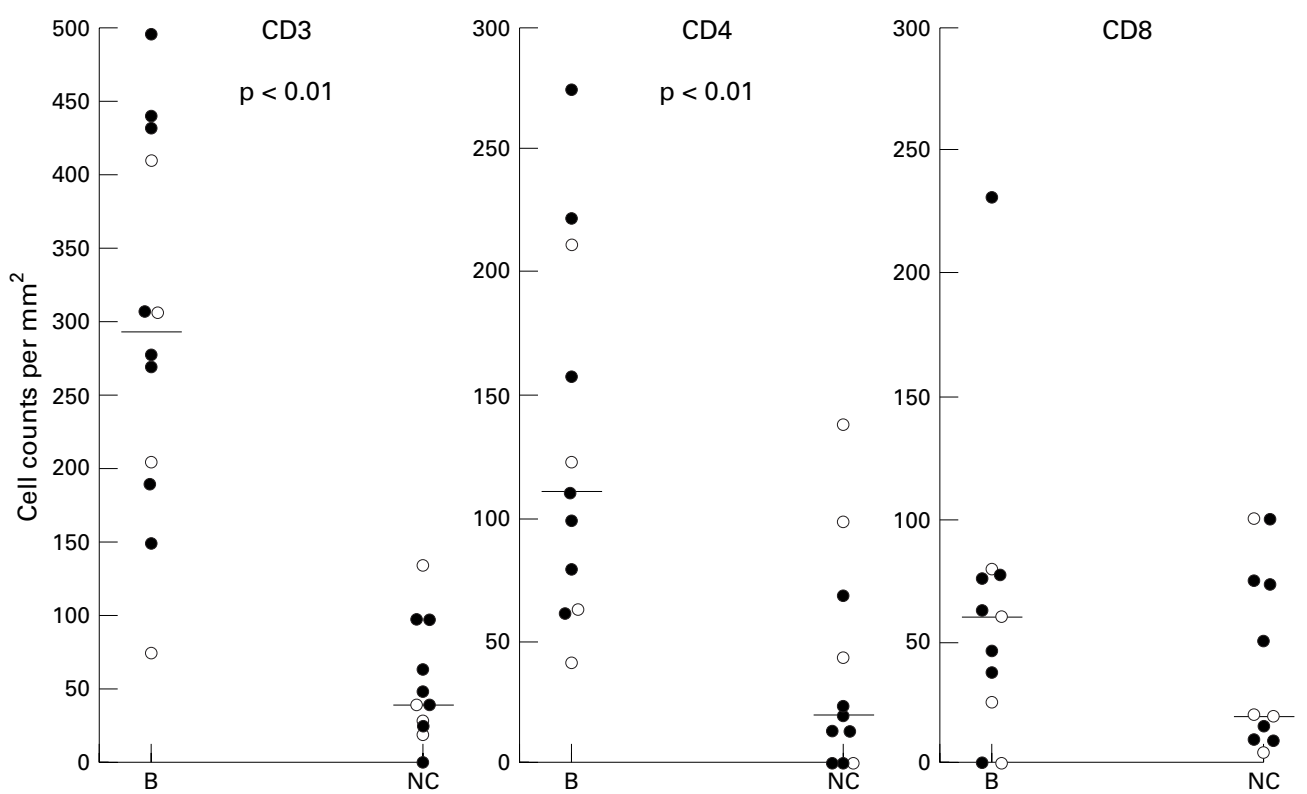

Figure 2 Individual counts for $C D 3, C D 4$, and $C D 8$ positive cells in the bronchial mucosa of patients with bronchiectasis $(B ; n=12,11$, and 11 , respectively) and normal control subjects $(N C ; n=11) ; \circ=$ atopic; $\bullet=$ non-atopic. Results are expressed as number of cells per $\mathrm{mm}^{2}$ of tissue section examined (average of at least two sections). Horizontal bars represent median values.

in patients with bronchiectasis and normal healthy controls was performed using the Mann-Whitney U test. Correlations between cell counts and/or clinical parameters were analysed using Spearman's rank method. $\mathrm{p}$ values of $<0.05$ were considered significant.

\section{Results}

Cellular infiltration in which mononuclear cells predominated was identified in the bronchial mucosa of all subjects including normal controls (table 2). In normal healthy controls neutrophils, macrophages and $\mathrm{T}$ lymphocytes were found in equal numbers and the CD4+/CD8+ ratio was 1.3:1. A more intense cellular infiltrate was observed in biopsy sections in patients with bronchiectasis compared with normal control subjects with CD45 cells 3.5 times the number seen in controls $(p<0.001$; fig 1$)$. In the bronchial mucosa of patients with bronchiectasis infiltrating cells were observed throughout the whole area of the sections examined with even more densely populated clusters arranged beneath the basement membrane. These cell aggregations contained mostly lymphocytes but other cell types were also noted. Assessment of the epithelium was inevitably impaired by artefactual damage and loss for both patients and controls, consequent upon the use of samples obtained endoscopically. However,

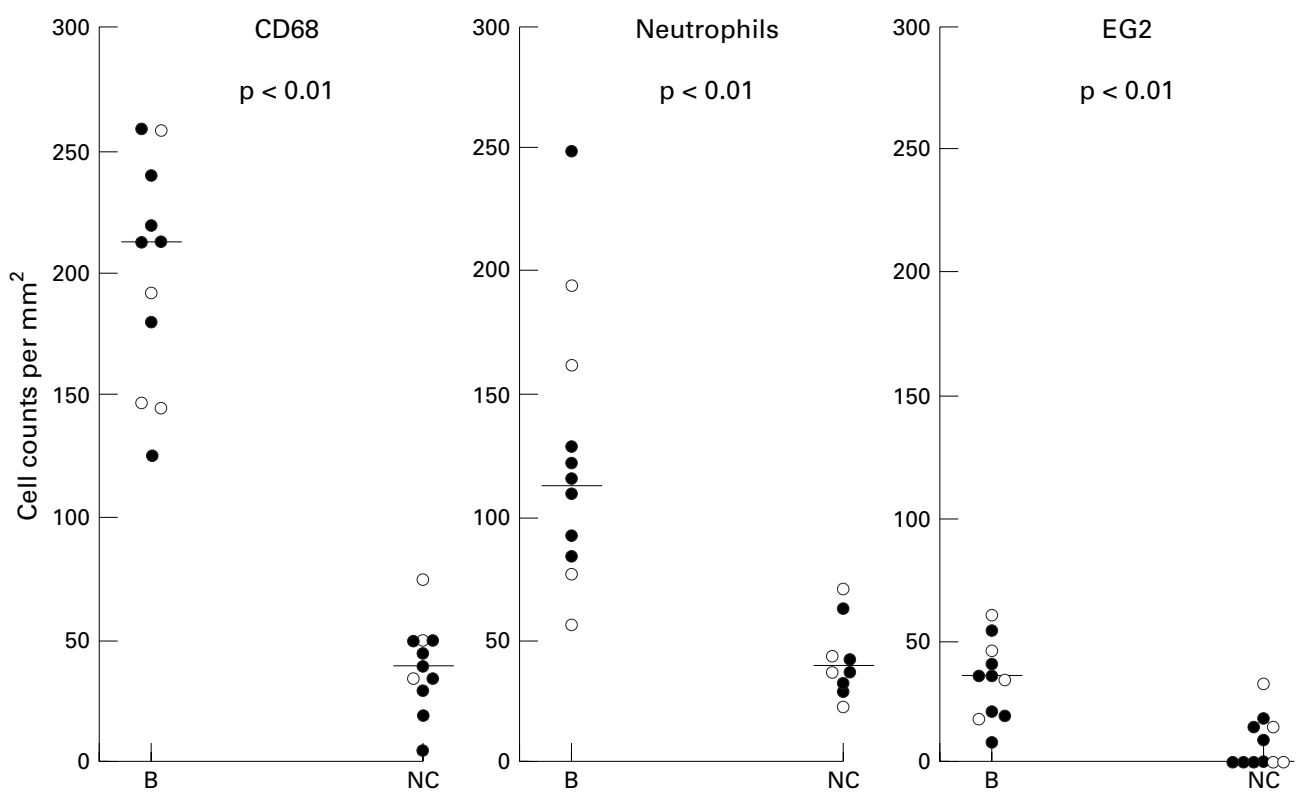

Figure 3 CD68, neutrophil, and EG2+ cell counts in the bronchial mucosa of patients with bronchiectasis $(B ; n=11,12$, and 11, respectively) and normal control subjects $(N C ; n=12) ; \bigcirc=$ atopic $; \bullet=$ non-atopic. Results are expressed as number of cells per $\mathrm{mm}^{2}$ of tissue section examined (average of at least two sections). Horizontal bars represent median values. 
Figure 4 IL-8+ cell counts in the bronchial mucosa of 12 patients with bronchiectasis (B) and eight normal control subjects $(\mathrm{NC}) ; \bigcirc=$ atopic; - = non-atopic. Results are expressed as number of cells per $\mathrm{mm}^{2}$ of tissue section examined (average of at least two sections). Horizontal bars represent median values.
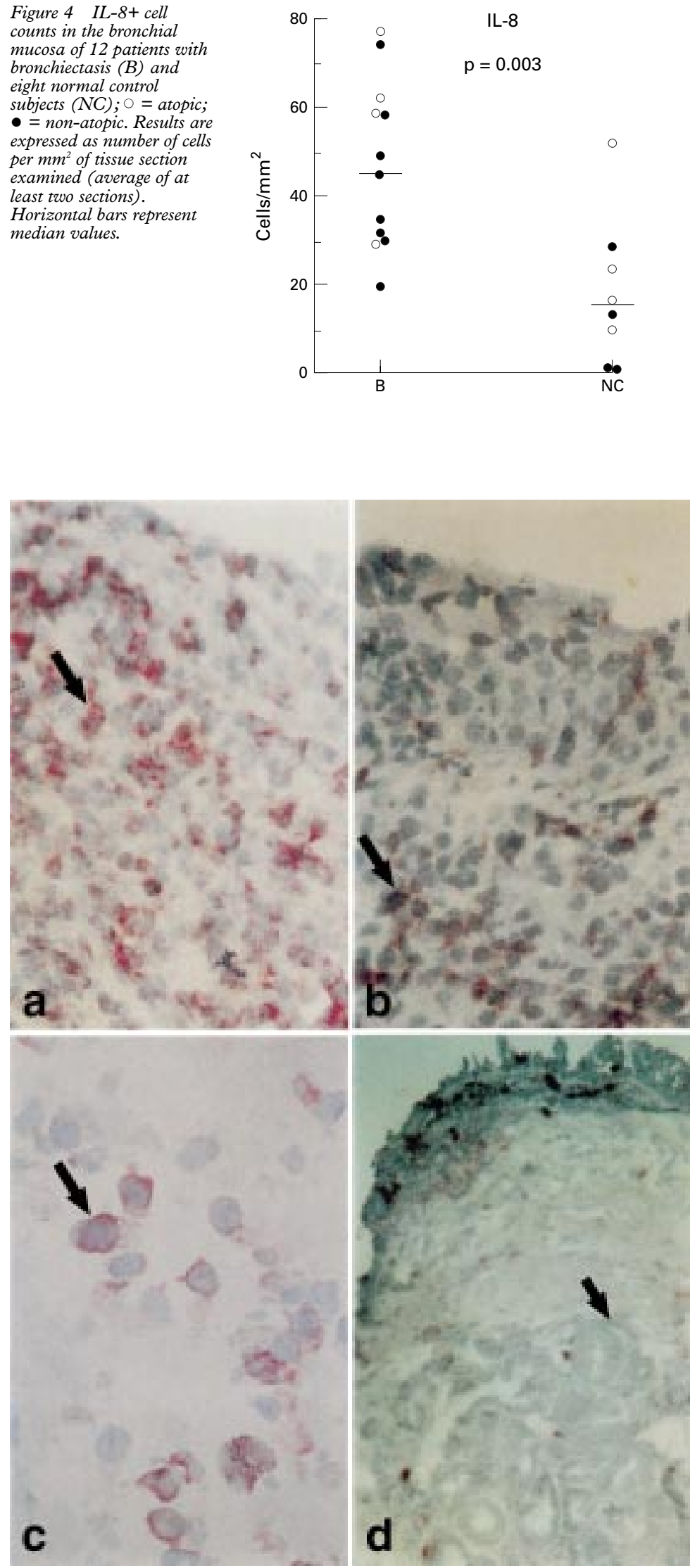

Figure 5 Photomicrographs of bronchial biopsy sections from patients with bronchiectasis (A) immunostained with anti-CD4 antibody (magnification $\times 400)$; (B) immunostained with anti-CD 8 antibody (magnification $\times 400$ ); and $(C)$ immunostained with anti-IL-8 (magnification $\times 1000$ ). (D) Photomicrograph from a patient with bronchiectasis showing abundant submucosal glands (magnification $\times 200$ ). Individual cells indicated by closed arrows. Position of bronchial lumen is at the top in $A, B$ and $D$ (not shown in $C$ ). when present the epithelium was intact in all cases and goblet cell hyperplasia was noted in most patients. Inflammatory infiltration of the epithelium was also noted. Mucosal gland hypertrophy was noted in over half of the biopsy sections in patients with bronchiectasis and in none of the normal control subjects $(\mathrm{p}<0.05)$. Mucous glands occupied over one third of the section area in three cases.

In patients with bronchiectasis there were increased numbers of CD3+ $\mathrm{T}$ lymphocytes compared with normal controls (median values, 422 cells $/ \mathrm{mm}^{2}$ versus 113 cells $/ \mathrm{mm}^{2}$, $\mathrm{p}<0.001), \mathrm{CD} 68+$ macrophages (213 cells/ $\mathrm{mm}^{2}$ versus 40 cells $/ \mathrm{mm}^{2}, \mathrm{p}<0.001$ ), elastase positive neutrophils $\left(114\right.$ cells $/ \mathrm{mm}^{2}$ versus 41 cells $\left./ \mathrm{mm}^{2}, \mathrm{p}<0.001\right)$, EG2+ eosinophils (36 cells $/ \mathrm{mm}^{2}$ versus 0 cells $/ \mathrm{mm}^{2}, \mathrm{p}<0.001$ ), and IL-8+ cells $\left(47\right.$ cells $/ \mathrm{mm}^{2}$ versus 15 cells $/ \mathrm{mm}^{2}$, $\mathrm{p}<0.01$; figs $2,3,4)$. CD $3+$ cells were the most numerous comprising mainly CD4+ cells with the $\mathrm{CD} 4+/ \mathrm{CD} 8+$ ratio being $3: 1$ in patients with bronchiectasis and 1.3:1 in normal control subjects. Within the bronchiectasis group CD3+ cell numbers were significantly lower in those patients on inhaled steroids than in those not taking inhaled steroids (197 cells/ $\mathrm{mm}^{2}$ versus 369 cells $\left./ \mathrm{mm}^{2}, \mathrm{p}<0.05\right)$, as were CD4+ cells (82 cells $/ \mathrm{mm}^{2}$ versus 190 cells/ $\left.\mathrm{mm}^{2}, \mathrm{p}<0.05\right)$, although the values remained significantly higher when compared with normal controls ( 18 cells $/ \mathrm{mm}^{2}, \mathrm{p}<0.001$; table 3 ). There were no significant differences for CD8+ and CD25+ cell counts between patients with bronchiectasis and normal controls, although there was a trend for higher cell numbers in those with bronchiectasis, particularly for CD25+ cells (table 2). IL-8+ cells were significantly lower in patients on inhaled steroids than in untreated patients (30 cells/ $\mathrm{mm}^{2}$ versus 60 cells $/ \mathrm{mm}^{2}, \mathrm{p}<0.05$ ), but again values in both groups of patients were higher than in control subjects $\left(15\right.$ cells $/ \mathrm{mm}^{2}$; tables 2 and 3$)$. There were no differences in total cell numbers (CD45+) or the numbers of macrophages (CD68+), granulocytes, or CD25+ cells in patients with bronchiectasis whether receiving or not receiving inhaled steroid treatment (table 3). Representative examples of cellular infiltration in the bronchial mucosa in patients with bronchiectasis can be seen in fig 5 .

\section{Discussion}

In this study we focused on the cellular infiltration in the bronchial mucosa of patients with post-infective bronchiectasis compared with corresponding bronchial biopsy specimens from normal healthy control subjects. The striking finding was an intense cellular infiltrate (with increased CD45+ cell numbers) with mononuclear cells (CD4+ $\mathrm{T}$ lymphocytes and macrophages), a prominent neutrophilia, and increased expression of the potent neutrophil chemoattractant IL-8. In those patients with bronchiectasis treated with inhaled steroids the $\mathrm{T}$ cell infiltrate (CD4+ cells) was significantly lower than in untreated patients. These findings support a role for cell mediated immune mechanisms in the pathogenesis of ongoing 
airways damage in bronchiectasis and its possible modulation by topical corticosteroids.

Previous immunohistological studies of bronchiectasis ${ }^{34}$ performed in an experimental rat model of bronchiectasis and on human subjects have identified a relative increase in CD8+ $\mathrm{T}$ lymphocytes in both control subjects and patients with bronchiectasis. Eller and coworkers $^{5}$ have recently examined bronchial tissue from 22 patients with bronchiectasis of diverse aetiology and found that CD8+ cells were predominant in two thirds of the patients. In the remaining biopsy sections CD4+ cells were predominant and these were mainly clustered in follicle-like structures. $\mathrm{T}$ cell phenotype in relation to disease aetiology was not reported. Control tissue samples were obtained from subjects with other respiratory conditions. The groups were matched for age but not atopic status and no information was provided on concomitant medication. Double immunofluorescence was used to assess CD4+/CD8+ ratios within the bronchial mucosa and no absolute counts are given. Neutrophil and eosinophil infiltration was not examined. In another study of bronchoalveolar lavage fluid in patients with bronchiectasis CD4+ and CD8+ cells assessed by flow cytometry were reported in equal numbers. ${ }^{6}$

In our study patients with bronchiectasis and normal controls were matched for atopic status. All subjects were current non-smokers. There was an excess of females among the bronchiectasis sufferers. There was an age difference between the two groups, with bronchiectasis patients being older. However, there was no correlation between age and the degree of cellular infiltration within the groups-that is, age did not account for any differences within groups. Similarly, differences in cell counts were maintained in subgroups of age matched patients. Patients with bronchiectasis showed a moderate or severe obstructive ventilatory defect on spirometric testing and this is in accordance with previously published data. ${ }^{17}$ Four of the patients with bronchiectasis showed reversibility of $>15 \%$ after administration of a $\beta_{2}$ agonist, although when expressed as an absolute change in $\mathrm{FEV}_{1}$ after bronchodilator the changes were small (in two patients the change was less than $0.2 \mathrm{l}$ ), and none of the patients gave a history suggestive of bronchial asthma. This small reversibility in patients with bronchiectasis is in agreement with previously published data on this disease. ${ }^{18}$ Biopsy samples were obtained in a standardised manner and validated immunohistological techniques with well documented commercial monoclonal antibodies were used (see Methods). An objective method of cell quantification was employed. ${ }^{10} 11{ }^{16}{ }^{19}$ Absolute CD4+ and CD8+ cell counts were recorded in addition to CD4+/CD8+ ratios and granulocyte infiltration was also examined. Such differences in subject characterisation, laboratory methods, and quantification may explain, at least in part, the differences between the studies. In keeping with our current findings of a predominant CD4+ $\mathrm{T}$ cell infiltrate in the bronchial mucosa in bronchiectasis patients and asymptomatic controls, similar increases in CD4+ T cells were observed in inflammatory conditions which may be associated with bronchiectasis, ${ }^{13}{ }^{14}$ as well as in bronchial asthma, ${ }^{10} 11$ chronic bronchitis, ${ }^{9}$ sarcoidosis, ${ }^{7}$ and normal subjects. ${ }^{10} 11$

Striking mononuclear recruitment in bronchiectasis has been suggested in a number of indirect studies in sputum. Owen and coworkers $^{20}$ showed that the mechanisms of influx of these cells into foci of infection and inflammation include enhanced CD11/CD18 integrin mediated adherence of monocytes to fibronectin. Neutrophils are another characteristic feature of the bronchial cell infiltrate in bronchiectasis. IL- 8 has been shown to be an important neutrophil chemoattractant in sputum from patients with cystic fibrosis, bronchiectasis, and chronic bronchitis and this may account, at least in part, for the recruitment of neutrophils into the airways of the patients. ${ }^{21}$

Eller and coworkers ${ }^{5}$ showed that IL-8 levels in the sputum of patients with bronchiectasis were high and remained high even during remission of infectious exacerbations. The presence of IL-8 was markedly increased in our study also, but was lower in those patients on inhaled steroids. We observed increased numbers of activated EG2+ eosinophils in the bronchial mucosa in patients with bronchiectasis although the numbers were small compared with neutrophil, macrophage, and $\mathrm{T}$ cell numbers. Eosinophils have been observed in the sputum of patients with bronchiectasis and numbers have been suggested to correlate with disease severity. ${ }^{22}$ Airway eosinophil activation is a feature of exacerbations of chronic bronchitis and is linked to disease severity. ${ }^{23}$ The significance of the increase in eosinophil numbers in bronchiectasis is not known, but disease severity - as shown by obstructive ventilatory defect - may account for it. The difference cannot be explained by atopic status as this was controlled for between the two groups.

Mucous gland hypertrophy was noted in patients with bronchiectasis and in some biopsy sections mucous glands occupied up to $40 \%$ of section area. Reid, in her pioneering work on the measurement of the mucous gland layer, reported increased gland area in bronchiectasis as well as in chronic bronchitis. ${ }^{24}$ Fahy et $a l^{25}$ have suggested that neutrophil proteases in the sputum of bronchiectasis sufferers induce a large secretory response from tracheal submucosal glands. Continuous and enhanced production of secretions may lead to mucous gland hypertrophy in time.

Bronchiectasis is characterised by an ongoing inflammation and our study showed that, even in the absence of an exacerbation, there is a marked cellular infiltration in the bronchial mucosa. Antibiotics effectively control the upsurge of inflammatory activity in acute exacerbations but have little effect on chronic airway inflammation. ${ }^{26}$ Anti-inflammatory treatment is the mainstay of treatment in asthma and studies testing the importance of anti-inflammatory treatment in chronic bronchitis are also currently under way. Inhaled indomethacin ${ }^{27}$ and inhaled steroids ${ }^{28}$ have been shown to have a beneficial effect in 
reducing symptoms in patients with bronchiectasis. Furthermore, bronchiectasis is associated with ciliary disorientation which may return to normal after prolonged inhaled steroid therapy. ${ }^{29}$ In our study a difference was observed between bronchiectasis patients treated with inhaled steroids and untreated patients, with the former group showing less $\mathrm{T}$ lymphocyte infiltration within the bronchial mucosa. Whether or not this is translated into clinical improvement (reduced symptoms and fewer exacerbations) is yet to be tested in a controlled trial.

Bronchiectasis sufferers are relatively few and it is considered to be an orphan disease. ${ }^{30}$ Nevertheless, the quality of life of these patients is severely affected and, because of frequent admissions to hospital, the cost of the disease is high. Our results confirm an intense mononuclear cell and neutrophil inflammatory infiltrate in bronchiectasis. Knowledge of cellular recruitment and infiltration mechanisms in bronchiectasis might lead to novel ways of modulating the disease, prevention of further deterioration in lung function, and better control of symptoms. Our results provide further support for the use of topical corticosteroids as well as antibiotic therapy for this disease, although further prospective controlled trials of inhaled corticosteroids are required. Strategies directed against either the CD4+ $\mathrm{T}$ cell infiltrate (such as anti-CD4 monoclonal antibodies) or IL-8 may have potential value.

1 Cole PJ, Wilson R. Host-microbial interrelationships in respiratory infection. Chest 1989;95:217-21S.

2 Whitwell F. A study of the pathology and pathogenesis of bronchiectasis. Thorax 1952;7:213.

3 Lapa E Silva JR, Jones JAH, Cole PJ, et al. The immunological component of the cellular inflammatory infiltrate in bronchiectasis. Thorax 1989;44:668-73.

4 Lapa E Silva JR, Guerreiro D, Noble B, et al. Immunopathology of experimental bronchiectasis. Am $\mathcal{f}$ Respir Cell Mol Biol 1989;1:297-304.

5 Eller J, Lapa E Silva JR, Poulter LW, et al. Cells and Eller J, Lapa E Silva JR, Poulter LW, et al. Cells and
cytokines in chronic bronchial infection. Ann NY Acad Sci 1994;725:331-45.

6 Mukae H, Kadota J, Kohno S, et al. Increase in activated CD8+ cells in bronchoalveolar lavage fluid in patients with diffuse panbronchiolitis. Am $\mathcal{F}$ Respir Crit Care Med 1995;152:613-8.

7 Campbell DA, du Bois RM, Butcher RG, et al. Density of HLA-DR antigen expression on alveolar macrophages is increased in pulmonary sarcoidosis. Clin Exp Immunol 1986;65:165-71.

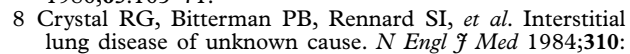
235-44.

9 Saetta M, Di Stefano A, Maestrelli P, et al. Activated T-lymphocytes and macrophages in bronchial mucosa of subjects with chronic bronchitis. Am Rev Respir Dis 1993;147:301-6.

10 Bentley AM, Menz G, Storz C, et al. Identification of T lymphocytes, macrophages and activated eosinophils in the bronchial mucosa in intrinsic asthma. Am Rev Respir Dis 1992;146:500-6.

11 Azzawi M, Bradley B, Jeffery PK, et al. Identification of activated $\mathrm{T}$ lymphocytes and eosinophils in bronchial biopsies in stable atopic asthma. Am Rev Respir Dis 1990;142:140713.

12 Poulter LW, Russel-Jones R, Hobbe S. The significance of antigen presenting cells in psoriasis. In: Macdonald DC, ed. Immunodermatology. London: Butterworths, 1984: $185-8$.

13 Poulter LW, Duke O, Panayi GS, et al. Activated T lymphocytes of the synovial membrane in rheumatoid arthritis and other arthropathies. Scand $\mathcal{f}$ Immunol 1985;22:683-9.

14 Poulter LW, Allison M, Rochardson AT, et al. The distribution of lymphocyte subsets in inflammatory bowel disease and reactive synovitis: a comparison. In: Mielants $\mathrm{H}$, Veys $\mathrm{EM}$, eds. Spondyloarthropathies: involvement of the gut. Amsterdam: Elsevier, 1987: 213-20.

15 Mason DY, Sammons R. Alkaline phosphatase and peroxidase for double immunising labelling of cellular contacts. F Clin Pathol 1978;31:454-60.

16 Frew AJ, Kay AB. The relationship between infiltrating CD4 positive lymphocytes, activated eosinophils and the magnitude of the allergen-induced late phase cutaneous reaction in man. F Immunol 1988;141:4158-64.

17 Currie DC, Pavia D, Agnew JE, et al. Impaired tracheobronchial clearance in bronchiectasis. Thorax 1987;42:126-30.

18 Murphy MB, Reen DJ, FitzGerald MX. Atopy, immunological changes and respiratory function in bronchiectasis. logical changes and resp

19 Bentley AM, Hamid Q, Robinson DS, et al. Prednisolone treatment in asthma: reduction in the numbers of eosinophils, $\mathrm{T}$ cells, tryptase-only positive mast cells $\left(\mathrm{MC}_{\mathrm{T}}\right)$ and modulation of interleukin-4, interleukin-5 and interferon gamma cytokine gene expression within the bronchial mucosa. Am f Respir Crit Care Med 1996;153: 551-6.

20 Owen CA, Campbell EJ, Hill SL, et al. Increased adherence of monocytes to fibronectin in bronchiectasis. Regulatory effects of bacterial lipopolysaccharide and role of CD11/ CD18 integrins. Am Rev Respir Dis 1992;145:626-31.

21 Richman-Eisenstat JB, Jorens PG, Hebert CA, et al. Interleukin-8: an important chemoattractant in sputum of patients with chronic inflammatory airway diseases. $A m \mathcal{F}$ Physiol 1993;264:L413-8.

22 Ip M, Lauder IJ, Wong WY, et al. Multivariate analysis of factors affecting pulmonary function in bronchiectasis. Respiration 1993;60:45-50.

23 Saetta M, Di Stefano A, Maestrelli P, et al. Airway eosinophilia in chronic bronchitis during exacerbations. Am 7 Respir Crit Care Med 1994;150:1646-52.

24 Reid L. Measurement of the bronchial mucous gland layer: a diagnostic yardstick in chronic bronchitis. Thorax 1960;15:132-41.

25 Fahy JV, Schuster A, Ueki I, et al. Mucous hypersecretion in bronchiectasis. The role of neutrophil proteases. Am Rev Respir Dis 1992;146:1430-3.

26 Ip M, Shum D, Lauder I, et al. Effect of antibiotics on sputum inflammatory contents in acute exacerbations of bronchiectasis. Respir Med 1993;87:449-54.

27 Tamaoki J, Chiyotani A, Kobayashi K, et al. Effect of indomethacin on bronchorrhea in patients with chronic bronchitis, diffuse panbronchiolitis or bronchiectasis. $A m$ Rev Respir Dis 1992;145:548-52.

28 Elborn JS, Johnstone B, Allen F, et al. Inhaled steroids in patients with bronchiectasis. Respir Med 1992;86:121-4

29 Rayner CF, Rutman A, Dewar A, et al. Ciliary disorientation in patients with chronic upper respiratory tract inflammation. Am F Respir Crit Care Med 1995;151:800-4.

30 Barker AF, Bardana EJ. Bronchiectasis: update of an orphan disease. Am Rev Respir Dis 1988;137:969-78. 